\title{
Light and Growth.
}

THE action of light on plants has had a perennial interest for plant physiologists, and recently the subject has received some concentrated attention. Ferdinand Hercik (Publications de la Faculté des Sciences de l'Université Masaryk, No. 74, 1926) has tried to correlate the action of light and the surface tension of the expressed sap of his plants. He finds that the sap of normally grown seedlings of Lupinus, Sinapis, and Pisum has a greater surface tension than sap from stems of etiolated seedlings. On the other hand, sap from leaves of normally grown seedlings has a smaller surface tension than sap from leaves of etiolated seedlings. Now etiolated plants have usually greater stem growth and less leaf growth than normal plants, and the author correlates the greater surface tension with less growth and the smaller surface tension with greater growth. If, however, seedlings have the same length, then the surface tension of their respective saps is the same irrespective of the conditions under which they have been grown. The author has not traced the causal chain between the surface tension of the sap and the actual phenomena of growth.

In a series of papers in the New Phytologist (vol. 24, 5, and vol. 25, 3 and 4), Prof. J. H. Priestley deals with the problem from a slightly different viewpoint and advances some tentative explanations of his results. In the case of the broad bean (Vicia Faba) he was able to destroy some of the more marked etiolation phenomena by only very brief exposures to light-. two minutes in every twenty-four hours. He points out that any change produced on etiolated plants by the action of light must be initiated, not by the effects of photosynthetic products, but by the photocatalytic effect of light upon the products of metabolism. For example, cells from the cortical region of an etiolated broad bean tip are incapable of being plasmolysed in a 17 per cent. cane-sugar solution, but, after exposure to artificial light for one hour on two successive days, are plasmolysed readily. The author considers that the photochemical action of light releases protein and fatty substances from the developing walls of the cells intervening between the central cylinder and meristem; and these walls, now consisting of purer cellulose, readily permit of the transfer of the nutrient sap from the central cylinder, with an ensuing more diffuse and more superficial development of merismatic tissue. In this way growth, which in the etiolated plant is confined to tips of stems, becomes redistributed.

The phototropic curvature of grass and cereal coleoptiles, the subject of much experimentation, is explained by Prof. Priestley on the basis of the foregoing hypothesis. Thus the side of the coleoptile exposed to the light becomes in consequence more permeable, with greater guttation through the apical hydathode from the vein nearer the light. The cells of the lighted side will therefore extend in length less than those of the darkened side, producing a curvature towards the light.

Following still another line of attark, Prof. Y. Yoshii has experimented on the influence of the relative length of day and night on plants (Science Reports of the Tôhoku Imperial University, 4th series, vol. 2, 2). His results, in the main, confirm and extend the work of Garner and Allard in grouping plants into two categories, long and short day plants, according to the length of daily illumination necessary for the production of flowers (Jour. Agri. Res., 1 8, p. 553, and 23, p. 871). The evidence adduced leads to the conclusion that there is probably another group of plants which are nearly or entirely indifferent to photoperiods, but affected by other factors as to time of flowering. The author finds that the optimum photoperiod for reproduction does not result in maximum vegetative growth, and that closely related plants, sometimes even varieties of the same plant, may behave quite differently as regards photoperiods; for example, the late variety of rice plant is a short day plant, while the early variety is indifferent to regulation of light period. This seems to suggest that some other factors besides those concerned in photosynthesis are involved. If the photoperiod is the key to the distinction between spring and winter varieties of wheat, then researches along this particular line may have some application in the practical field of crop production.

\section{Yorkshire Ammonites. ${ }^{1}$}

THE amateur geologist who collects Yorkshire ammonites may approach the collection of papers before us with expectation, but he is likely to be disappointed if he hopes to identify his specimens from the descriptions there given. The work is not for the amateur, but for the specialist; and even he will have to dig deep in involved sentences to find the information which only so patient and expert a worker as Dr. Spath can give. These little papers have really an immense scope, gathering up and pronouncing upon outstanding uncertainties in the systematics of the main groups to which belong all ammonites commonly found in the Lower Lias; supplying new generic names where needed; and tilting at the evolutionary conceptions of previous ammonite workers.

To promote the first aim, Dr. Spath appeals to Yorkshire geologists to go into the field and collect Yorkshire ammonites bed by bed. In proposing new generic names, he considers that the quotation of a genotype is sufficient diagnosis. That would be more justifiable if the genotype were a species known by 1 Hull Museum Publications, No. 143. "Notes on Yorkshire
Ammonites." A pril-July, Sept.-Dec., 1925; Feb., May, June, Sept., Nov., 1926. an existing holotype, and not mainly or merely by a figure. It is also probable that ammonite specialists the world over will miss the new genera thus casually proposed in notes on a local fauna in a journal which caters for amateur naturalists rather than professional palæontologists.

The fact is that Dr. Spath has tried to pack into these modest papers matter far beyond their scope, and he has condensed it almost to the limits of intelligibility. We feel that he could expand his remarks on evolution into an enthralling thesis, but here we can catch only the barest outline of his scheme. He has nothing but scorn for those who find comfort in supposed ammonite lineages, but he does not give them instead a clear-cut theory of evolution. The following points, however, seem to stand out: (1) The two great families, namely, Phylloceratidæ and Liparoceratidæ, persisted almost unchanged throughout the Mesozoic, and were the radical stocks whence group after group repeatedly sprang, rapidly evolved in many directions, and quickly died out. (2) Already in Triassic time all possible forms of ornament and whorl-shape had been tried, only to reappear again and again in later stocks (we must not say lineages). This seems to support

No. 2997, VoL. 119] 
a doctrine of Trends. (3) Even within a single species the young show very great variability, and on reaching maturity converge to a common form, thus refuting, in Dr. Spath's opinion, the doctrine of post-embryonic recapitulation. (4) New characters often appear first in the young, again proving that the doctrine of post-embryonic recapitulation is unsound. All these evolutionary pronouncements are of great interest, and would bear critical consideration, but here they can only be noticed, not discussed.

\section{University and Educational Intelligence.}

BRISTOL. -The following appointments have been made: In the Department of Chemistry, Dr. W. E. Garner, University College, London, to be professor of physical chemistry in succession to Prof. J. W. McBain, and Dr. Morris W. Travers, to be reader in applied physical chemistry and an honorary professor of the University. In the Department of Physics, Dr. J. E. Lennard-Jones, reader in mathematical physics, to be professor of theoretical physics; Dr. H. W. B. Skinner to a Henry Herbert Wills research fellowship in physics. Dr. L. C. Jackson was also appointed to a Henry Herbert Wills research fellowship some time ago.

It is hoped that the building of the Henry Herbert Wills Physics Laboratory will be completed in the summer, and that it will be ready for use by the beginning of next session.

Cambridge.-Field-Marshal Sir William Birdwood has been elected to an honorary fellowship at Peterhouse, a College with which he is closely connected by family ties.

R. O. Redman, St. John's College, has been elected to the Sheepshanks Exhibition in astronomy at Trinity College. The subject for the Adams Prize for the period 1927-28 is announced as "The Variations in the Earth's Magnetic Field in Relation to Electric Phenomena in the Upper Atmosphere and on the Earth." A theoretical contribution to the origin of the various phenomena and their qualitative and quantitative relations with each other is asked for.

Lonbon. - The following Doctorates have been conferred: D.Sc. in statistics on Mr. E. C. Rhodes (University College) for a thesis entitled (1) "On a Skew Correlation Surface," (2) "The Precision of Means and Standard Deviations when the Individual Errors are correlated," (3) "The Comparison of Two Sets of Observations "; D.Sc. (Engineering) on Mr. W. H. J. Vernon (Imperial College-Royal Sehool of Mines) for a thesis entitled "The Atmospheric Corrosion of Metals (Second Experimental Report to the Atmospheric Corrosion Research Committee)."

Manchester.-Dr. Alex. M. Smith has been appointed lecturer in agricultural chemistry and adviser under the Ministry of Agriculture advisory scheme.

THE Ella Sachs Plotz Foundation has issued its third annual report, from which it appears that thirty-eight applications for assistance in 1926 were received. Thirteen grants were made, seven of them to scientific workers outside the United States. For the present, research on problems in medicine and surgery is favoured, and preference is given to a group of investigations on a single subject; for example, four grants have been given each year for work bearing on the subject of chronic nephritis. Applications for grants for 1927-28 should be sent to Dr. Francis W. Peabody, Boston City Hospital, Boston, Massachusetts, before May 15.

\section{Calendar of Discovery and Invention.}

April Io, 1864.- The modern process of manufacturing open hearth steel was started by PierreEmile Martin, who melted together pig-iron, scrap, and iron ore in a Siemen's regenerative furnace. Martin's French patent was taken out on April 10, 1864. Two hundred years ago, Réaumur described the conversion of wrought iron into steel by fusing it with pig-iron, but his experiments never went beyond the laboratory stage. The open hearth process was introduced into America in 1868. In 1880 that country produced 1,074,000 tons of Bessemer steel, and 110,000 tons of open hearth steel. Forty years later these figures had increased to $8,883,000$ tons of Bessemer steel, and 32,672,000 tons of open hearth steel, the total production being nearly equal to half a ton of steel per head of population.

April II, I 709. - The most famous of all prizes for scientific work is the Copley Medal of the Royal Society. It was founded by Sir Godfrey Copley, Bart., who by his will dated Oct. 14, 1704, and proved April 11, 1709, bequeathed to Sir Hans Sloane and Abraham Hill " one hundred pounds in trust for the Royal Society of London for improving natural knowledge, to be laid out in experiments or otherwise for the benefit thereof as they shall direct and appoint." No award was made until 1731, when Stephen Gray, an inmate of the Charterhouse, received a prize for his electrical experiments. On Nov. 10, 1736, the Royal Society resolved to convert the bequest into a gold medal, Desaguliers receiving the first, and since then the medal has generally been awarded annually. Copley was a member of Parliament and held various public offices. In 1881 the then representative of the family, Sir Joseph Copley, transferred to the Royal Society a sum in Consols sufficient to provide in perpetuity an annual bonus of $£ 50$ to be given to the recipient of the medal (v. also Nature, Dec. 4, 1926, p. 823).

April 13, 1869. - The successful braking of trains was first solved by Westinghouse. A head-on collision between two trains directed his attention to the matter, and the chance reading of an account of the use of compressed air in boring the Mont Cenis Tunnel led to his experiments with an air brake. His first steam-air brake was patented on April 13, 1869. In 1872 he described the automatic brake, and the following year brought out his ingenious triple valve. In the famous trials on trains carried out by Sir Douglas Galton in 1878-9, the brake of Westinghouse proved its superiority, but it was afterwards much improved, Westinghouse alone taking out altogether 103 patents in connexion with it.

April I 5, x777.- A hundred and fifty years ago, in a letter dated April 15, 1777, Volta suggested to Prof. Barletti of Pavia the possibility of firing a pistol at Milan by the discharge of Leyden jars at Como, the two places being joined by an iron wire.

April I 5, I 845.--Liebig is regarded as the virtual founder of agricultural chemistry. His famous work, it was on a barren plot of land outside Giessen that he made his experiments. His researches also led to the foundation of the artificial manure industry, and he himself, through James Muspratt, on April 15, 1845, took out an English patent, the object of his invention being " to restore to the land by means of a manure the mineral elements taken away by the crop which had been grown on and removed from the land.'

April 1 5, 1893.-The finest pre-turbine British liner was the s.s. Campania, which on trial on April 15, 1893, developed 31,050 h.p. and attained a speed of 23.18 knots, her displacement being $\mathbf{1 8 , 0 0 0}$ tons. E. C. S.

No. 2997, VoL. 119] 